\title{
PERANAN ANGGARAN PRODUKSI SEBAGAI DASAR PENGHITUNGAN BIAYA PEMAKAIAN BAHAN BAKU PADA UD. SUMBER AGUNG LAMONGAN
}

\author{
*(Titin \\ Prodi Manajemen, Fakultas Ekonomi, Universitas Islam Lamongan \\ Jl. Veteran No.53A Lamongan \\ Telp. ( 0322 ) 324706, Faks. ( 0322 ) 324706 \\ Email :jpim.unisla@gmail.com
}

\begin{abstract}
ABSTRAK
Anggaran produksi dibuat untuk menunjang biaya pemakaian bahan baku dan mengatur tingakat produksi sedemikian rupa sehingga perhitungan baiaya pemakaian bahan baku dapat lebih efektif dan efisien, oleh karena itu diperlukan anggaran produksi yang tepat, apabila dalam anggaran produksi tidak diikuti dengan perhitunganbiaya pemakaian bahan baku, maka akan mengakibatkan biaya yang dikeluarkan tidak sesuai yang dibutuhkan.Berdasarkan uraian diatas, maka penulis mengambil judul penelitian "peranan anggaran produksi sebagai dasar penghitungan biaya pemakaian bahan baku pada UD. Sumberagung lamongan”, dengan menggunakan alat analisa metode ful cosing apakh peranan anggaran produksi di UD. Sumberagung Lamongan sudah efektif.
\end{abstract}

Kata kunci : anggaran produksi dan pemakaian bahan baku

\section{PENDAHULUAN}

Dalam mengahadapi persaingan yang semakin ketat dalam dunia usaha saat ini, banyak cara yang dilakukan dan dikembangkan untuk mencapai tujuan secara efektif dan efisien, sehingga perlu adanya pemikiranpemikiran dan pengkajianpengkajian untuk mendapatkan cara yang lebih baik guna menghasilkan outputsecara baik dan dapat mencapai sasaran secara tepat waktu, tepat jumlah, dan berkualitas dengan biaya yang seminimal mungkin.

Demi menjamin kelancaran proses produksi serta menjaga kelangsungan hidup perusahaan maka perusahaan harus membuat alternatif cara pengadaan perhitungan biaya pemakaian bahan baku yaitu dengan membuat anggaaran produksi, agar anggaran produksi berfungsi dengan baik, maka estimasi yang memuat didalamnya harus cukup akurat, sehingga tidak jauh berbeda dengan realisasinya, untuk itu diperlukan data informasi dan pengalaman yang merupakan faktor-faktor yang harus dipertimbangkan dalam anggaran produksi.

Anggaran produksi dibuat untuk menunjang biaya pemakaian bahan baku dan mengatur tingakat produksi sedemikian rupa sehingga perhitungan baiaya pemakaian bahan baku dapat lebih efektif dan efisien, oleh karena itu diperlukan anggaran produksi yang tepat, apabila dalam anggaran produksi tidak diikuti dengan perhitunganbiaya pemakaian bahan baku, maka akan mengakibatkan biaya yang dikeluarkan tidak sesuai yang dibutuhkan. 


\section{METODE PENELITIAN}

Jenis penelitian yang dilakukan adalah penelitian asosiatif kausal.Menurut Umar (2003 : 30) penelitian asosiatif kausal adalah "penelitian yang bertujuan untuk menganalisis hubungan antara satu variable dengan variable lainya atau bagaimana suatu variable mempengaruhi variabel lain". Dengan kata lain desain kausal berguna untuk mengukur hubungan-hubungan antar variable riset atau berguna untuk menganalisis bagaimana suatu variable mempengaruhi variabel yang lain.

Penelitian sendiri di artikan sebagai suatu penyelidikan atau usaha pengujian yang di lakukan secara teliti dan kritis dalam mencari fakta-fakta dan menggunakan langkah-langkah tertentu, dalam mencari fakta-fakta ini diperlukan usaha yang sistemati suntuk menemukan jawaban ilmiah suatu masalah. Di sisilain tujuan dari sebuah penelitian digunakan untuk mengembangkan suatu metode, menguji serta mengemukakan kebenaran suatu masalah atau pengetahuan. Penelitian sejatinya adalah kegiatan yang objektif yang dilakukan berdasarkan prinsip-prinsip atau teori-teori yang disusun secara sistematis melalui proses yang intensif. Kemudian masalah adalah titik sentral atau focus dari penelitian itu sendiri.

Untuk menghindari kesalah pahaman tentang pengertianpengertian yang dimaksud dengan penelitian maka disini perlu untuk diberikan penjelasan mengenai variabel yang dipakai.Adapun variable tersebut adalah :

1) Variabelbebas

independent variable (X) Menurut suharsimi arikunto( 2006 : 119) variable bebas adalah "variabel yang mempengaruhi sebab timbulnya variabel lain". Dalam hal ini variable bebas (X) yang digunakan dalam penelitian ini adaalah pemakaian anggaran Produksi

2)Variabel terikat / dependent variable (Y) Menurut suharsimi arikunto ( $2006: 119)$ variable terikat adalah "varibel yang dipengaruhi oleh variable bebas". Didalam penelitian ini variable terikatnya yaitu Biaya Bahan Baku.

Dalam penelitian ini penulis menggunakan metode analisis data kuantitatif yaitu cara untuk menganalisis data yang bersifat kuantitatif yang pada umumnya berbentuk model matemati satau angka-angka yang dapat dibuat sebagai dasar pengambilan keputusan. Dan untuk menjawab permasalahan-permasalahan yang telah diajukan perlu dianalisis data. Didalam melakukan analisis data maka teknik yang dipergunakan adalah :

Harga pokok biaya produksi menurut metode full costing terdiri dari

1. Biaya bahan baku

2. BiayaTenagaKerjaLangsung

3. Biaya Overhead PabrikTetap

4. Biaya Overhead PabrikVariabel

5. HargaPokokProduksi

Dalam metode full costing biaya overhead pabrik baik yang yang berprilaku tetap maupun variabel, dibebankan kepada produk yang diproduksi atas dasar tarif yang ditentukan dimuka pada kapasitas normal atau atas dasar biaya overhead pabrik sesungguhya, oleh karna itu biaya overhead tetap akan melekat pada harga pokok persediaan produk dalam proses dan persediaan 
produk jadi yang belum laku dijual dan dianggap sebagai biaya ( angsur harga pokok penjualan) apabila produk jadi tersebut telah dijual.

\section{HASIL PENELITIAN DAN PEMBAHASAN}

Dalam rangka mengadakan pemecahan masalah yang dihadapi oleh perusahaan penyunsun akan menelitih semua biaya - biaya yang masuk dalam atau yang berkaitan dengan biaya produksi agar tidak terjadi kesalahan dalam penghitungan biaya produksi dan penulis juga akan menentukan hargajual produk sebagai dasar harga jual roti tersebut penulis juga membuat laporan laba - rugi menurut penghitungan metode full costing dan variabel costing

\section{Penentuan Harga Jual}

Beras kwalitas dua

Harga Pokok Produksi :

Biaya bahan baku Rp. 83.273.577,75

Biaya tenaga kerja langsung $\mathrm{Rp}$. 41.472 .000

Biaya overhead pabrikRp 21.712.475,25

Rp 146.458.053

$=146.458 .053+(30 \% \quad \mathrm{x}$ $146.458 .053)$

$=190.395 .468,9$

$=190.395 .468,9: 96.000$

Harga $=6.930 / \mathrm{Kg}$

Dari penghitungan diatas dapat diketahui biaya anggaran produksi dan biaya anggaran bahan baku.

Beras kwalitas satu

Harga Pokok Produksi :

Biaya bahan baku

$$
\text { Rp. 101.778.817,25 }
$$

Biaya tenaga kerja langsung

$$
\text { Rp. 50.688.000 }
$$

$$
\begin{aligned}
& \text { Biaya overhead pabrik Rp } \\
& \text { 26.537.469,75p 179.004.287 } \\
& =179.004 .287+(3 \% \times 179.004 .287)
\end{aligned}
$$

$=232.705 .573,1$

$=232.705 .573,1: 96.000$

Harga $=7.580 / \mathrm{Kg}$

Dari penghitungan diatas dapat diketahui biaya anggaran produksi dan biaya anggaran bahan baku.

\section{- Metode Full Costing}

Yakni merupakan metode penentuan harga pokok produksi, yang membebankan seluruh biaya produksi baik yang berperilaku tetap maupun variable kepada produk. Dikenal juga dengan Absortionatau Conventional Costing.

Harga Pokok Produksi :

Biaya bahan baku

$$
\text { Rp. 185.052.395 }
$$

Biaya tenaga kerja langsung Rp. $\quad 92.160 .000$

Biaya overhead pabrik tetap Rp.45.322.945

Biaya overhead pabrik variabel

$$
\begin{gathered}
\text { Rp } \quad 2.927 .000 \\
\text { Harga Pokok Produk } \\
\text { Rp. } 325.462 .340
\end{gathered}
$$

Penyajian Laporan Laba Rugi

Laporan Laba - Rugi

( Metode Full Costing )

Hasil penjualan

Rp 423.101.104,2

Harga pokok penjualan

Laba Bruto

$$
\text { Rp } 322.535 .340
$$

Rp 100.565.764,2

Biaya administrasi dan umum Rp 1.463 .500

Biaya pemasaran

$$
\underline{\mathrm{Rp}} 1.463 .500
$$

Laba Bersih Usaha

\section{Rp97.638.764,2}

\section{KESIMPULAN DAN SARAN Kesimpulan}

Anggaran produksi sebagai dasar penghitunganbiaya bahan baku yang diterapkan oleh UD. Sumberagung sudah tepat. 
Dari hasil penghitungan harga jual yang dilakukan oleh penyusun maka harga jual untuk kategori beras kwalitas dua Rp. 6.930 untuk kategori beras kwalitas satu Rp7.580.Berdasarkan penghitungan metode full costing dan variabel costing maka dari hasil produksi roti pada tahun 2014 sebesar Rp 325.462.340, Dan dari laporan laba rugi manurut full costing dan variabel costing laba bersih yang di peroleh oleh perusahaan sebesar Rp 97.638.762.

\section{Saran}

$\begin{array}{ccc}\text { Untuk menetapkan } & \text { harga } \\ \text { pokok perusahaan } & \text { harus }\end{array}$ memasukan semua biaya seperti biaya pemakaian bahan baku ,biaya tenaga kerja dan biaya over head pabrik sehingga dapat di temukan hasil yang tepat yang diinginkan perusahaan.

Untuk menentukan harga jual perusahaan harus menentukan marjin terlebih dahulu sehingga dapat menentukan laba dan harga jual yang di inginkan

\section{DAFTAR PUSTAKA}

Brigham, Eugene F. and Louis Gapenski, 2001. Financial Management (Theory and Practice). 7 th Ed The Dryden Press, Harcout Brace Collage Publishers, Singapore.

Finnerty, John D., 2006. Coorporate Financial Analysis, First Ediition, McGraw-Hill, Inc. New York.

Helfert, Erich A., 2007. Teknik Analisis Keuangan: Petunjuk Praktis Untuk mengelola dan Mengukur Kinerja Perusahaan. Terjemahan : Herman Wibowo, Erlangga, Jakarta.

Husnan, Suad dan Enny Pudjiastuti, 2012. Dasar-dasar Manajemen Keuangan, Edisi Kedua. UPP AMP YKPN, Yogyakarta.
Kennedy, Ralp D. and Stewart Y. McMullen, 2013. Financial Statements, Form, Analysis and interpretation. Sixth Edition, Richard D. Irwin, Inc. Homewood, Jakarta.

Munawir, S. 2008. Analisa Laporan Keuangan. Edisi Keempat. Yogyakarta : Liberty Yogyakarta.

Rangkuti, Freddy, 2008. Analisis SWOT Teknik Membedah Kasus Bisnis, Edisi Pertama, Cetakan Ketujuh, Gramedia Pustaka Utama, Jakarta.

Sawir, Agnes., 2003. Analisis Kinerja Keuangan dan Perencanaan Keuangan Perusahaan. Penerbit PT. Gramedia Pustaka Utama, Jakarta.

Scott, William R., 2010. Financial Accounting Theory. PrenticeHall, Inc.

Syamsuddin, Lukman., 2009. Manajemen Keuangan Perusahaan, Edisi Baru, Gramedia Pustaka Utama, Jakarta.

Van Horne, James C., 2013. Dasardasar Manajemen Keuangan, Edisi Keenam, Terjemahan : Marianus Sinaga, Erlangga, Jakarta.

Weston, J. Fred \& Copeland Thomas E., 2012: Alihbahasa Waksana, Jaka \& Kibrandoko. Manajemen Keuangan. Jilid I Penerbit Erlangga, Jakarta.

White, Gerald I, A.C. Sondhi, and D. Fried, 2002. The Analysis and Use of Financial Statements, Second Edition. John Whiley \& Sons, Inc. 